\title{
Budućnost žene: filozofska rasprava o utopiji i feminizmu
}

\author{
Plejada, Institut za društvena istraživanja u Zagrebu, 2015., Zagreb, \\ 248 str.
}

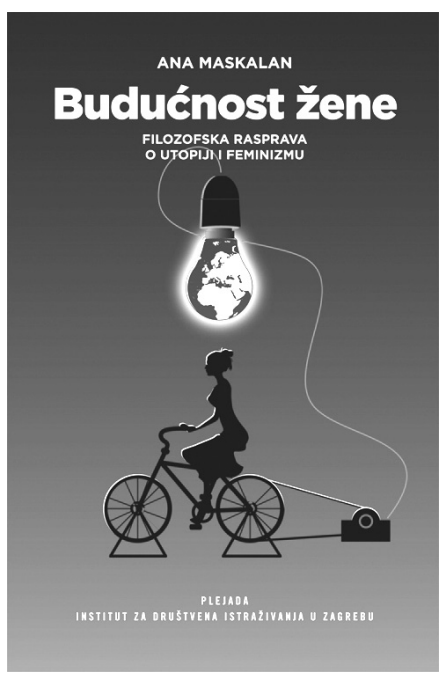

Knjiga Budućnost žene: filozofska rasprava o utopiji i feminizmu Ane Maskalan proizašla je iz doktorske disertacije. Knjiga je podijeljena u trinaest poglavlja (ne uzimajući u obzir zaključak): Čemu utopija? Čemu budućnost žene?; Utopija - etimološki usud; Korijeni utopije: korijeni prijepora; Utopijska književnost: subverzivna moć umjetnosti; Smrt utopije - dva lica; Filozofija nade, filozofija utopije; Predutopijska žena; Žena klasične utopije; Feminističke ideje utopijskih socijalista; Feminizam i utopija; Kult ženskosti kao sudbina i prokletstvo: feminističke utopije 18. i 19. stoljeća; Utopijska subverzija statičnih koncepata: feminističke utopije 20. stoljeća; Postmodernizam, feminizam, utopizam - gdje je utopija?

Maskalan iz filozofske perspektive sistematično pristupa analizi utopije i utopijskog mišljenja. Kombinirajući analizu teorijskih pristupa utopiji s kritičkim promišljanjima brojnih primjera predutopijskih djela, klasičnih i feminističkih književnih utopija i djela utopijske društvene i feminističke teorije, prikazuje historijski razvoj utopije i njezine predutopijske korijene te problematizira važnost utopije i utopijskog mišljenja za suvremenost, posebno za feminizam. Također, Maskalan konstantno podsjeća kako pri razumijevanju prikazanih djela ne smijemo izgubiti iz vida sociohistorijski kontekst njihovog nastanka, što vodi tome da se mnoge utopije proglašavaju neozbiljnim sanjarijama, a njihove ideje olako odbacuju kao zastarjele i time beznačajne.

Maskalan je prije svega stalo do obrane utopije i utopijskog mišljenja koje je u suvremenosti dovedeno u pitanje proglašavanjem njegova kraja ili negiranjem njegovih pozitivnih odrednica. Istovremeno želi ukazati na važnost feminizma za utopijsko mišljenje. Na tragu toga je i glavna teza koja se odnosi na poimanje feminističke misli kao inherentno utopističke. Pri problematiziranju postojećih prijevoda i mogućih značenja pojma utopija autorica se priklanja suvremenim interpretacijama utopije 
kao „dobrog mjesta kojega nema“, premda upozorava da se time u konačnici utopija predstavlja ne samo kao dobro mjesto nego i kao savršeno, čime se negira mogućnost promjene postojećeg, što određuje kao jedan od ključnih kriterija utopije.

Korijeni utopije nalaze se u antičkom i židovsko-kršćanskom predutopijskom nasljeđu, odnosno Platonovom dijalogu Politeja, te biblijskim opisima Edenskog vrta i proročanstvu o dolasku Mesije. Maskalan se u prikazu tog nasljeđa ponajprije oslanja na analize Manuela i Manuela, Kumara i Chertkove. Antičko se nasljeđe očituje u ideji grada kao mjesta utopije, dok se židovsko-kršćansko nasljeđe očituje u smještanju utopije u određeno vrijeme, točnije u budućnost. Također, u prvome je bolji svijet djelo čovjeka, dok je u drugome Božje djelo. Maskalan upravo kriterij utopijskog stvaratelja određuje kao ključno razlikovno obilježje utopije. Prema Chertkovoj, ključni Platonov doprinos predstavlja zagovor racionalnog mišljenja i znanja, nasuprot mitu kao osnovi antičkog mišljenja.

Književnost se pokazuje kao najznačajniji medij utopijskog mišljenja u periodu od 15. do kraja 18. stoljeća, a Moreova Utopija kao mjesto nastanka utopijske književnosti i djelo čije su glavne motive preuzimali gotovo svi kasniji utopijski književnici. Oslanjajući se na promišljanja Vieire, Kumara i Roemera, Maskalan objašnjava da je književnost postala značajno mjesto utopijskog mišljenja zbog mogućnosti relativno sigurnog iznošenja subverzivnih političkih ideja, odnosno utopijske kritike. Također, dotiče se odnosa utopije i žanra znanstvene fantastike te distopija, koje usprkos posjedovanju svih utopijskih elemenata primat daju utopijskoj kritici.

U narednim dvama poglavljima Maskalan se nastavlja baviti teorijskim razmatranjima utopije. Kritikom utopije bavi se u poglavlju „Smrt utopije - dva lica kritike“. Pozivajući se na Jurića, Jacobyja i Jamesona, smrt utopije dovodi u vezu sa suvremenim tumačenjima koja izjednačavaju utopiju i totalitarne režime. Popper je najznačajniji zagovornik takvog izjednačavanja. On također dovodi u sumnju i osnovnu utopijsku pretpostavku o mogućnosti ostvarenja boljeg društva na temelju razuma i znanosti. Prema Maskalan, iz takvog stava proizlaze dvije posljedice: odustajanje od razuma u osmišljavanju boljeg svijeta i odustajanje od promjene svijeta. Također, negativan utjecaj na razvoj utopijskog mišljenja izvršile su i Darwinova evolucionistička teorija, Freudova teorija o nesvjesnim i nagonskim aspektima ljudskih bića te znanstvene paradigme biheviorizma i pozitivističkog realizma. Nakon toga prikazuju se dvije velike struje utopijske kritike: marksistička i neoliberalna. Marksistička se zasniva na Marxovoj i Engelsovoj kritici utopijskog socijalizma, odnosno kritici mirnih promjena kao metodi ostvarenja utopije, nasuprot revolucionarnom djelovanju. Neoliberalna kritika zasniva se na tezi o kraju povijesti, koji za nužnu posljedicu ima kraj utopije (Fukuyama), te nestajanju mašte i rezigniranom stavu spram budućnosti, što se u suvremenom dobu vidi kao u mnogočemu slično sadašnjosti (Jacoby).

U poglavlju „Filozofija nade, filozofija utopije“ razmatraju se razlika između utopije i utopizma, odnos utopije i ideologije te se posebna pažnja poklanja Blochu i njegovoj filozofiji nade, za kojega Maskalan već u uvodnom dijelu kaže da je nadahnuo njezina stajališta o utopiji. Blochova filozofija nade predstavlja „centralno mjesto razumijevanja utopijskog mišljenja“ (str. 80), budući da upravo nada omogućava 
mišljenje promjene, odnosno utopijsko mišljenje. Uz utopijsku kritiku i utopijsku maštu ona je jedan od triju temeljnih aspekata utopijskog mišljenja. Također, problematizira se (ne)razlikovanje utopije i utopizma. Pritom se kao ključna pokazuju promišljanja Chertkove, Villoroa te posebno Kangrge. Utopizam se odnosi na problem praktičnog ostvarenja utopije, a zasniva se na odbacivanju postojećeg svijeta, koji se vidi kao potpuno neadekvatan, te ga se stoga zamjenjuje idealnim svijetom. Maskalan kao osnovnu pogrešku utopizma određuje uvjerenje da je ideal ostvariv. Viđenje odnosa ideologije i utopije dvojako je. Tendenciju njihovog vezivanja problematiziraju Sargent i Bosanac, dok Bloch i Mannheim inzistiraju na strogom razlikovanju. Maskalan zaključuje kako strogo razlikovanje ideologije i utopije, koje se temelji na njihovoj različitoj funkciji, ima određene nedostatke, te stoga određuje pravednost kao glavni kriterij razlikovanja utopije i ideologije. Pravednost podrazumijeva ravnopravnost ljudi i međusobno poštivanje usprkos postojanju razlika. U tom smislu feminizam se opet pokazuje kao fundamentalno utopijski, dok se pred utopije koje promišljaju odnose moći postavlja zahtjev da nužno moraju biti feminističke.

U poglavljima „Predutopijska žena“ i „Žena klasične utopije“ vraća se antičkom i židovsko-kršćanskom nasljeđu te književnosti razmatrajući ulogu žena u predutopijskim i klasičnim utopijskim djelima. Uspoređujući mit o Pandori i progonu iz Edenskog vrta Maskalan zaključuje kako se bez obzira na neke razlike u obama slučajevima odgovornost za pojavu svih zala na svijetu svaljuje na ženu. Govoreći o Platonu problematizira se njegov doprinos feminizmu. Maskalan zaključuje da se glavni Platonov doprinos feminizmu nalazi u njegovom razlikovanju spola i roda, koje proizlazi iz uvida o važnosti društvenog konteksta za položaj žena.

Glavna zamjerka koju Maskalan upućuje klasičnim utopistima tiče se neprepoznavanja potrebe poboljšanja društvenog položaja žena. U nastavku fokus se usmjerava na tri djela: Utopiju Thomasa Morea, Grad sunca Tommasa Campanelle i Novu Atlantidu Francisa Bacona. Od spomenutih djela Moreova Utopija pokazuje se kao najprogresivnija budući da pretpostavlja mogućnost obavljanja klerikalnih dužnosti kao jedine javne funkcije koja je dodijeljena ženama. Međutim dužnosti vezane uz rad u pravilu ostaju u domeni tradicionalnih poslova, dok u bračnom odnosu žena ostaje podređena mužu. Stoga Maskalan zaključuje da, promatrano iz suvremene perspektive, žene Utopije ipak žive distopiju.

U 19. stoljeću utopijska društvena teorija i utopijske zajednice postaju glavni oblici izražavanja utopijskog mišljenja. Ti oblici utopijskog mišljenja značajni su po tome što se u njima prvi put problematizira društveni položaj žene. Fourier i Saint-Simon izdvajaju se kao najznačajniji za uvođenje feminističkih ideja u utopijsko mišljenje, odnosno za razvitak budućeg feminističkog pokreta. Dapače, Maskalan tvrdi da je u odnosu na njegove suvremenike i ostale utopijske socijaliste Fourierova misao najrevolucionarnija po tome što je smatrao da se rodna ravnopravnost treba ostvariti kako u javnoj tako i u privatnoj sferi. Značaj Saint-Simona vezuje se prvenstveno uz nastavljače njegovih ideja - sensimoniste. Za razvoj feminističkog pokreta najznačajnije je djelovanje ženskih nastavljačica Saint-Simonovih ideja, koje su oformile časopis Forum žena te koje su zagovarale važnost zajedničkog i o muškarcima neovisnog političkog djelovanja žena. 
U nastavku Maskalan se bavi odnosom feminizma i utopije, karakteristikama feminističkih utopija te utjecajem postmodernističke teorije na feminističko (utopijsko) mišljenje. U tom smislu ponavlja se osnovna teza o inherentnoj utopičnosti feminizma i važnosti feminizma za preživljavanje utopijskog mišljenja u suvremenosti, što proizlazi iz zagledanosti feminizma u (bolju) budućnost žene. Glavna karakteristika feminističkih utopija jest njihova refleksivnost spram feminističkog nasljeđa. Oslanjajući se na promišljanja Brammer, Maskalan specifičnost i važnost feminističkih utopija pronalazi upravo u tome što ih stvaraju Drugi. Izlažu se dva primjera najranijih feminističkih (pred)utopijskih djela: Knjiga o gradu žena ili Grad žena Christine de Pizan i Opis novog svijeta koji se zove Plamteći svijet Margaret Cavendish. Djelo De Pizan Maskalan određuje kao predutopijsko stoga što utopijski stvaratelj grada nije čovjek te se autorica ne bavi opisom boljeg društva, nego kritikom mizoginih stavova. Djelo Cavendish pokazuje se kao osobito značajno zato što je autorica iznijela viziju društvenog položaja žene potpuno drukčiju od njezinih suvremenika, te je stoga zaslužna za „reviziju klasične utopijske paradigme“ (str. 163).

18. i 19. stoljeće određeno je kao period ranih feminističkih utopija. Te utopije tematiziraju obrazovanje kao jedan od osnovnih ciljeva feminističkog pokreta prvog vala te kult ženskosti koji počiva na ideji esencijalnih razlika muškaraca i žena, nekada ga kritizirajući, a nekada nekritički prihvaćajući. Zapravo je „balansiranje između zahtjeva za ravnopravnošću s jedne strane i podilaženja kultu ženskosti s druge strane još jedna karakteristika ranih feminističkih utopija“ (str. 170). Kult ženskosti osim rodne ima i rasnu komponentu, u smislu da se ženskost vezuje uz svijetlu put.

Pri problematizaciji karakteristika feminističkih utopija 20. stoljeća Maskalan se oslanja na Little, Pearson i Gearhart. Te utopije naglasak stavljaju na određenje boljeg društva i važnost individualne slobode i autonomije. To drugo osobito se očituje u feminističkim separatističkim utopijama, koje, uz androginske utopije, predstavljaju najčešći tip feminističkih književnih utopija 20. stoljeća. Osim njih postoji još i tip utopija u kojima je zadržana podjela na spolove. Analiza feminističkih književnih utopija započinje kritičkim osvrtom na Njenozemsku Charlotte Perkins Gilman, budući da je to najranije djelo perioda te se u njemu problematiziraju teme koje će feminističke utopije narednih razdoblja dodatno razrađivati. U nastavku se daje prikaz niza feminističkih utopija iz perioda drugog vala, koji se označava kao zlatno doba feminističkih utopija. Te utopije određuju se kao kritičke ili subverzivne, karakterizira ih ambivalentnost prema utopijskoj nadi u bolju budućnost, transgresija tradicionalnih binarizama zapadne filozofske i teološke misli, problematiziranje koncepta linearnog vremena te ispreplitanje utopijskih i distopijskih slika. Pri prikazu utjecaja feminističkih teorija na književna utopijska djela kao značajne autorice izdvajaju se Butler i Millet, kojoj Maskalan posvećuje znatnu pažnju. Njezina teoretiziranja pokazuju se kao osobito značajna za tip androginskih utopija. Kada su u pitanju separatističke utopije, Maskalan je izrazito kritična prema njima, prvenstveno stoga jer počivaju na esencijalizaciji spolnih razlika. Pri prikazima književnih utopija znatna pažnja se posvećuje Ursuli Le Guin i njenim dvama romanima, ekotopiji Čovjek praznih šaka i androginskoj utopiji Lijeva ruka tame. Prvi je značajan zbog toga što utopijsko mjesto nije prikazano kao mjesto obilja, već konstantne borbe za opstanak. Tu Maskalan iznosi zanimljivu opservaciju o tome kako suvremena 
kriza utopije možda proizlazi upravo iz „svijesti da predstojeća borba postaje borba za održanjem i da to održanje nužno zahtjeva muku, napor, odricanje, patnju i neizvjesnost" (str. 192). Drugi roman, s temom društva koje nastanjuju bića čije su spolne oznake i reproduktivne sposobnosti promjenjive, reflektira teorijski koncept Butler o performativnosti roda i spola. Na samom kraju poglavlja Maskalan razmatra strategije koje feminističke utopistice koriste za nadilaženje spomenutih binarizama i koncepta linearnog vremena. U najvećoj se mjeri oslanja na promišljanja Sargisson. Ona zagovara strategije vezane uz žensko pisanje i jezične igre, tzv. „utjelovljenje teksta“, te heterogeni pogled na drugost, čija je značajna posljedica dokidanje utopije kao strogo propisanog nacrta za bolju budućnost. Usko uz to vezana je i strategija transgresije linearnog vremena, koja se očituje u narativnoj nedovršenosti feminističkih utopija te miješanju utopijskih i distopijskih elemenata. S obzirom na rečeno Maskalan zaključuje kako feministička utopija, u odnosu na tradicionalnu, predstavlja „novi oblik manifestacije utopijskog“ (str. 201).

Maskalan knjigu završava osvrtom na odnos postmodernističke teorije i feminizma te mogućnost feminističkog utopijskog mišljenja u vremenu postmodernizma. Unutar feminizma kritika utopije na tragu postmodernističkih stavova tipično se javlja u okviru trećeg vala, a Maskalan posebno izdvaja Kitch, koja smatra da utopijsko mišljenje, koje je totalizirajuće, homogenizirajuće i okrenuto budućnosti, onemogućava djelovanje feminističkog pokreta „sada i ovdje“. Također, kao sporna mjesta feminističkog (utopijskog) mišljenja u vremenu postmodernizma pojavljuju se fluidnost rodnog identiteta i politika identiteta. Za Butler je politika identiteta po svojim političkim posljedicama istovjetna biološkom determinizmu. S druge strane, koncept fluidnosti identiteta, koji se javio kao odgovor na spomenute nedostatke politike identiteta, za Benhabib je problematičan jer dokida jasni subjekt feminističke politike te onemogućava političko djelovanje pokreta i mogućnost utopističkog zamišljanja potrebnih strategija za unapređivanje budućnosti. Teoretičari/ke utopije rješenje pronalaze u pojmu nove utopije, koja je postmoderna, kritična, dvosmislena, ambivalentna otvorena ideja promjene nabolje. S obzirom na inherentnu utopičnost feminizma, odustajanje feminizma od utopije za Maskalan je politički neprihvatljivo jer vodi vlastitoj negaciji. Jedan od oblika nove utopije, koji zagovara Johnson, jest „smješteno utopijsko mišljenje“ na tragu ideja interaktivnog univerzalizma Benhabib i koncepta utjelovljene utopije koji razvija Grosz. Neki od drugih prijedloga već su spomenuta transgresivna utopičnost Sargisson te strategija „uradi sam“, koju feministički pokret dijeli s alterglobalističkim pokretima. Maskalan zaključuje poglavlje i knjigu osvrtom na potencijale socijalističkih i marksističkih ideja za feministički pokret, osobito na suvremene uvide koji se tiču odnosa roda i klase, kakvi su prisutni u promišljanjima Čakardić. Pri tome kao polazište uzima opservaciju Poldervaart o novoj utopijskog snazi feminizma koju pronalazi u utopijskom socijalističkom feminizmu te zagovor Bahovec za potrebom nadilaženja „feminističke Realpolitike“ ukoliko se želi održati utopijska misao unutar feminizma.

Budućnost žene predstavlja obavezno štivo za sve zainteresirane za povijest feminizma te mogućnosti i ograničenja utopijskog ozbiljenja feminističke misli. Knjiga obiluje iznimno zanimljivim primjerima predutopijskih djela te feminističkih i klasičnih utopijskih djela, od kojih mnoga nažalost nisu našla svoje mjesto u ovome prikazu. 
U tom smislu teorijska i literarna analiza je bogata, dok se iz teksta iščitava autoričina strast za feminizmom i utopijom te fascinacija utopijskim književnim djelima.

Marina Petras

Doktorandica studija sociologije na Filozofskom fakultetu Sveučilišta u Zagrebu 